\title{
Development of Project Based Handouts in Algebra Structure Course
}

\author{
Alfiani Athma Putri Rosyadi \\ University of Muhammadiyah Malang, Indonesia \\ Email: athmaputri@gmail.com
}

\begin{abstract}
This study aims to describe the steps of development of project-based hand out on the algebra structure course. Subjects in this study are students who are taking course algebra structure. The research approach used is descriptive qualitative. The instruments of data collection used are: 1) questionnaire, 2) observation sheet, 3 ) interview and 4) Test The results of the research resulted that the steps of developing the project based hand out are: 1) needs analysis, 2) determining the learning objectives to be achieved, 3) constructing project based hand out, 4) validating, 5) revising the validator, 6) handout test in small group and 7) produce hand out product. Suggestions for future researchers should be able to collaborate with other methods and can develop with an interactive hand out product.
\end{abstract}

Keywords: Development, project-based Handout, Algebraic Structure

\section{INTRODUCTION}

The structure of algebra is one of the compulsory subjects in the mathematics education program. There are several prerequisites for the course of algebraic structure, such as yautu: 1) discrete mathematics, 2) linear algebra, 3) algebra, 4) calculus and 5) basic logic. In fact, even though the students are in the procedure already taking the prerequisite course, but conceptually and procedurally is still weak. This is shown based on the observation result from 2014 until 2016, the following data are obtained: 1) Students have not mastered the prerequisite subject so that when studying the core material still need to repeat the previous material, 2) the minimum reference held by the students, 3 ) have difficulty in completing the practice of proof and concept comprehension and 4) the students have not understood the application of material in everyday life.

Problems that appear on the student can be given alternative solutions. Improvement in the learning process is one of the actions that can be done. Improved learning process can be derived through the preparation of learning, implementation of learning and evaluation of learning. One of the things that can be done is when the implementation of learning with the improvement of methods and teaching materials used during the learning process [7]. Learning materials that can be used include: 1) textbook, 2) Learning module, 3) Hand Out Learning and 4) Student Activity Sheet.

Hand Out learning is one of the teaching materials in which there are learning objectives, material summary, sample questions and practice questions. Hand Out is given to the students at each meeting. In the hand out there are several activities, including: 1) I learned today, in which there are learning objectives to be achieved at the meeting, 2) Summarize, in which there is a summary of the material and the important points of learning are discussed, 3) My reflection, in which there are prerequisite materials that are discussed at a glance to recall, 4) my practice, there are examples of questions and exercise questions done by students to apply the knowledge they have gained, 5) Project tasks, in which there are tasks done independently and group by students, and 6) my reflection in which there are responses and reflections by students that can be used as a reference for the preparation of the next hand out.

Project based learning is part of the learning process that places emphasis on problem solving as a collaborative effort in a particular learning period. Implementation can be tasks that students do independently or in groups so that it can produce a real product in everyday life. The task given to the student contains about the relevance of the material discussed with the application in everyday life. For example an example can be taken: Discuss with your group's friends, how to technique Software for the computer exercises in this chapter is available at the website: http://www.d.umn.edu/ jgallian 1) This software computes the inverse of any element in GL(2, $\mathrm{Zp}$ ), where $\mathrm{p}$ is a prime, 2) This software prints the elements of $U(n)$ and the inverse of each element. [1]

\section{RESEARCH METHODS}

This type of research is research and development (research and development). Research and development is a research method used to produce a particular product and test the effectiveness of the product. This research is developing research-based hand out. The approach

used is descriptive qualitative

The subjects of this study are students who are taking the course of algebraic structure. Small groups applied hand out are students who are taking the course of algebraic structure with 3 students in low category, 3 students in medium category and 3 students in high category.

In this study the procedure is in accordance with the following steps. 1) Preliminary Analysis. At this stage the researcher reviews the reference and curriculum for the preparation of research-based hands out, 2) Develops research-based handouts, 3) Validation of media and material experts, 4) revisions of project-based handouts, 5)

Implementation of project-based handouts, 6) Data collection and 7) Data Analysis

Data were collected through: questionnaires, interviews and observation sheets. 
1. Questionnaire

Questionnaires are structured to determine the effectiveness of handouts that have been developed. Can students understand the concepts presented in project-based hand out activities

2. Interview Interviews are used to explain data obtained through questionnaires and observations in the classroom. Data collection using interviews is expected to be more in-depth information obtained from students.

3. Observation Sheet The observation sheet is used to determine the readability and implementation of researchbased handouts.

4. The test is used to classify student groups that will be tested using project-based handouts

\section{RESULT AND DISCUSSION}

Based on the results of research on project-based handout development, the following steps are obtained

1. Based on the results of the needs analysis obtained that the project-based hand out produced consists of: a) I learned today, in which there are learning objectives to be achieved at the meeting, b) Summarize, in which there is a summary of materials and points, c) My reflections, in which there are prerequisite materials that are discussed at a glance to recall, d) my practice, which examples of problems and exercise questions done by students to apply the knowledge they have gained, e) Project tasks, in which there are tasks done independently and groups by students, and f) my reflection in which there are responses and reflections by students who can be used as a reference for the preparation of the next hand out.

2. The learning objectives of the hand out are divided into five: a) Describes the definition of binary operations, b) provides an example of an operation that fulfills binary operations, c) lists cayley to define a binary operation in a set, d) , e) mentions an example and not a group instance

3. Preparing project-based handouts in accordance with the results of the study on the needs analysis step and has been adapted to the learning objectives

4. Validate the material and media experts. Validator consists of three lecturers who are competent in the field, it is intended to be able to provide appropriate advice. Based on the validation results obtained an average of 85.67 bis very good and valid category.

TABLE 1. REsUlt From The VALIDATOR

$\begin{array}{cc}\text { Validator } & \text { Score } \\ \text { I } & 87 \\ \text { II } & 86 \\ \text { III } & 84 \\ \text { Average } & 85,67\end{array}$

5. To revise the validator, namely: 1) Uniformity and consistency of handout display, 2) Addition of relevance to prerequisite courses and 3) Additions to the exercise questions.

6. Test hand out on small groups. After revising the three validators the next step is to test the small group. This small group contains at least three groups of students that are low-ability, moderate, and high-ability students. Students selected are students who are taking the course of algebra structure. Based on the results of the test, the students were involved: 1) Low group (AA, RK, RT), 2) students with medium group

(YY, FH, KK), and 3) students with high group (OK, PP, LM)

7. Produce hand out products that have been applied to small groups of students.

\section{CONCLUSIONS AND SugGestions}

The results of the research resulted that the steps of developing the project based hand out are: 1) needs analysis, 2) determining the learning objectives to be achieved, 3) constructing project based hand out, 4) validating, 5) revising the validator, 6) handout test in small group and 7) produce hand out product. Suggestions for future researchers should be able to collaborate with other methods and can develop with an interactive hand out product

\section{REFERENCES}

[1] A. Gallian and D. Rusin, "Factoring Groups of Integers Modulo n," Mathematics Magazine 53 (1980) Trans. Roy. Soc. London, vol. A247, pp. 529-551, April 1955. (references)

[2] D. Shanks, Solved and Unsolved Problems in Number Theory, 2nd ed., New York: Chelsea, 1978. 3.

[3] Washburn, T. Marlowe, and C. Ryan, Discrete Mathematics, Reading, MA:Addison-Wesley,1999.K. Elissa, "Title of paper if known," unpublished.

[4] Lillian Kinkade and Joyce Wagner, "When Polynomial Rings Are Principal Ideal Rings," Journal of Undergraduate Mathematics 23 (1991): 59-62.

[5] Linda Deneen, "Secret Encryption with Public Keys," The UMAP Journal 8 (1987): 9-29.

[6] Suherman, Erman dkk. 2003. Strategi Pembelajaran Matematika Kontemporer. Bandung : UPI.Sdfds

[7] Oemar, Hamalik. 2005. Proses Belajar Mengajar. Bandung: PT Bumi Akasara.

[8] Abdul Majid, Perencanaan Pembelajaran: Mengembangkan Standar Kompetensi Guru, PT Remaja Rosdakarya. 2007 